\title{
Effect of additives and filling methods on whole plant corn silage quality, fermentation characteristics and in situ digestibility
}

\author{
Ting Jiao ${ }^{1 * *}$, Zhaomin Lei ${ }^{2}$, Jianping $\mathrm{Wu}^{2,3}$, Fei $^{2} i^{2}$, David P. Casper ${ }^{4}$, Jianfu Wang $^{2}$, and Jianxin Jiao ${ }^{2}$
}

\section{* Corresponding Author: Ting Jiao \\ Tel: +86-0931-7634057, \\ E-mail: jiaoting207@126.com}

${ }^{1}$ College of Grassland Science, Key Laboratory of Grassland Ecosystem, Gansu Agricultural University, Lanzhou 730070, China

${ }^{2}$ College of Animal Science and Technology, Gansu Agricultural University, Lanzhou 730070, China

${ }^{3}$ Animal Husbandry, Pasture and Green Agriculture Institute, Gansu Academy of Agricultural Sciences, Lanzhou 730070, China

${ }^{4}$ Casper's Calf Ranch, 4890 West Lily Creek Road, Freeport, IL 61032, USA

ORCID

Ting Jiao

https://orcid.org/0000-0003-0839-5177 Zhaomin Lei

https://orcid.org/0000-0002-8144-6623 Jianping Wu

https://orcid.org/0000-0001-9470-9210 Fei Li

https://orcid.org/0000-0002-5915-0199 David P. Casper

https://orcid.org/0000-0002-0666-8808 Jianfu Wang

https://orcid.org/0000-0003-0821-0849

Jianxin Jiao

https://orcid.org/0000-0002-4274-3158

Submitted Nov 26, 2020; Revised Jan 5, 2021; Accepted Feb 27, 2021
Objective: This project aimed to evaluate the effects of both different additives and filling methods on nutritive quality, fermentation profile, and in situ digestibility of whole plant corn silage.

Methods: Whole plant corn forage harvested at 26.72\% dry matter (DM) was chopped and treated with two filling methods, i) fill silos at one time (F1), ii) fill silos at three times (F3), packing samples into one/three silo capacity at the first day, another one/three capacity at the second day, then one/three at the third day, three replicates. For each replicate, samples were treated with three additives, i) control (CTRL, no additive), ii) Sila-Max (MAX, Ralco Nutrition Inc., Marshall, MN, USA), and iii) Sila-Mix (MIX, Ralco Nutrition Inc., USA). With three replicates of each secondary treatment, there were nine silos, 54 silos in total. Each silo had a packing density of $137.61 \mathrm{~kg}$ of $\mathrm{DM} / \mathrm{m}^{3}$. All silos were weighed and stored in lab at ambient temperature.

Results: After $60 \mathrm{~d}$ of ensiling, all items showed good silage fermentation under MAX filled one time or three times $(p<0.01)$. Higher silage quality for all additives was obtained at filling one time than that filled three times $(p<0.01)$. The highest DM and lowest DM loss rate (DMLR) occurred to MAX treatment at two filling methods $(\mathrm{p}<0.01)$; Digestibility of acid detergent fiber, neutral detergent fiber (NDF), and curde protein had the same results as silage quality $(\mathrm{p}<0.01)$. Yield of digestible DM and digestible NDF also showed higher value under MAX especially for filling one time $(\mathrm{p}<0.05)$.

Conclusion: All corn silages showed good fermentation attributes $(\mathrm{pH}<4.0)$. The forage filled one time had higher silage quality than that filled three times $(p<0.01)$. MAX with homofermentative lactic acid bacteria enhanced the lactic acid fermentation, silage quality and nutrient digestibility, and so improved the digestible nutrient yield.

Keywords: Corn Silage; Filling Times; Silage Additives; Silage Quality

\section{INTRODUCTION}

China is an agricultural country with abundant straw resources. More than 8.4 billion tons of straw is produced every year [1]. In traditional agriculture, straw is mainly used for fertilizer, fuel and feed without any treatment [2]. Only a small part of straw is treated as feed [3]. Low protein, poor palatability and low digestibility restrict the use of straw for ruminants, leading to a waste of natural resources. Therefore, how to improve the utilization rate of straw feed is really essential. Ensiling is one of the most widely practiced processing methods. Corn silage forms the bulk of most dairy cattle rations in China and is a process that preserves valuable feedstuff for a long period of time [4]. Different fermentation aids and processing methods affect silage fermentation characteristics and quality. Silage additives affect fermentation patterns and aerobic stability in different ways according to their specific mode of action [5]. These additives are added to prevent or reduce the growth of undesirable microorganisms in silage and thus enhance silage fermentation and aerobic 
stability [6]. One of these additives, organic acid with strong antifungal properties has been used to increase silage aerobic stability [7]. And another additive such as acetic acid bacteria was used to improve silage aerobic stability after discovering high concentrations of acetic acid in aerobically exposed corn silages contaminated with high populations of Acetobacter pasteurianus [8]. And, interestingly, there was a contradictory notion that buffered acid mixtures stimulated ethanol [9]. For which notion there is an affirmative need to verify in practice. And more, ensiling is impossible to complete in one day if the silage volume is large, often requiring several days to complete. However, differences in the changes that feed quality undergoes during ensilage between these two situations are still not known. Therefore, the objective of the experiments was to evaluate the effects of various existing chemical additives, filling types and their interactions by analyzing corn silage fermentation characteristics, nutritional value, nutrient digestibility, and the yield of digestible nutrients in corn silage.

\section{MATERIALS AND METHODS}

\section{Forage and treatments}

Whole plant corn forage (unknown variety, approximately $26.72 \%$ dry matter $[\mathrm{DM}]$ ) at dough stage maturity, harvested by a forage chopper (680, Juancheng Mechanical Equipment Co., Guangzhou, China) on October 1, 2015, on a dairy farm in Lintao county, Gansu, China was chopped to a theoretical length of cut of $1 \mathrm{~cm}$ [10]. Samples were collected to determine initial DM and nutrient composition. The chopped sample was manually packed into laboratory silos (polyethylene bottles with screw caps, $20 \mathrm{~L}$ capacity). There were two filling methods, i) fill silos at one time (F1), ii) fill silos at three times (F3), that is packing samples into one/three capacity of the silo at the first day, another one/three capacity at the second day, then the last one/three at the third day, three replicates of each treatment. For each replicate, the sample was treated with three additives, i) control (CTRL, no additive), ii) Sila-Max (MAX, Ralco Nutrition Inc., Marshall, MN, USA), and iii) Sila-Mix (MIX, Ralco Nutrition Inc., USA). Max contained dried L. plantarum, dried E. faecium, $P$. acidilacitici, dried $P$. acidipropionici, fruct-oligosaccharide and starch, with adding dosage of $2.5 \mathrm{~g} / \mathrm{t}$ fresh forage, dissolved in $4 \mathrm{~L}$ deionized water, then sprayed on forage evenly, supplied a final application rate of $2.5 \times 10^{8}$ of lactic acid bacteria (LAB)/kg fresh forage; Mix contained the following active ingredients: lactic acid (LA), dried L. plantarum, dried $P$. acidilactici, dried E. faecium, dried P. acidipropionici, dried Bacillus subtilis, dried Aspergillus, fructo-oligosaccharide, starch, iron oxide and cobalt-lactic, with adding dosage of $1.0 \mathrm{~kg} / \mathrm{t}$ fresh forage, the same method on forage, supplied a final application rate of $1.8 \times 10^{6}$ of $\mathrm{LAB} / \mathrm{kg}$ fresh forage. The same amount of deionized water was also applied to CTRL. With three replicates of each secondary treatment, there were nine silos, 54 silos in total. Each silo had a packing density of $137.61 \mathrm{~kg}$ of $\mathrm{DM} / \mathrm{m}^{3}$. All silos were weighed and stored in lab at ambient temperature. After $60 \mathrm{~d}$ of storage, the silos were weighed, opened, and samples were collected for measurement of nutrients concentrations, nutrients digestibility, $\mathrm{pH}$, ammonia, volatile fatty acid (VFA), LA, and lowest DM loss rate (DMLR).

\section{Chemical analyses}

Both fresh juice and silage juice were extracted by blending $10 \mathrm{~g}$ forage (wet basis) in $90 \mathrm{~mL}$ of distilled water through double-layered cheesecloth and filter paper (Xinhua Co, Hangzhou, China). The mixture was stored for $24 \mathrm{~h}$ at $4^{\circ} \mathrm{C}$ in a refrigerator [11], and the filtrate was used for $\mathrm{pH}$, ammonia$\mathrm{N}, \mathrm{LA}$, and VFA determination. The $\mathrm{pH}$ was directly measured using a pH meter (PHS-3C, Youke Instrument Co., Shanghai, China); $\mathrm{NH}_{3}-\mathrm{N}$ was measured using phenol-hypochlorite method according to Broderick and Kang [12]. LA and VFA concentrations were determined with a high-performance liquid chromatography (HPLC) system using an SB-AQ $\mathrm{C}_{18}$ column and G132B ultraviolet fluorescence detector (1260 Infinity, Agilent Technologies, Boston, MA, USA). The total VFA concentrations include LA concentrations.

Both fresh and silage samples were dried by placing them in a forced-air oven at $65^{\circ} \mathrm{C}$ for $48 \mathrm{~h}$ to determine $\mathrm{DM}$ and then were ground to pass through a $1 \mathrm{~mm}$ screen using a grinding mill (SJP-500 A Jinsui Mechanical Equipment Co., Yongkong, Zhejiang, China) and stored for analysis [13]. The crude ash (Ash) concentration was measured by placing a 1 $\mathrm{g}$ sample in a muffle furnace set at $560^{\circ} \mathrm{C}$ for $5 \mathrm{~h}$. Total nitrogen (TN) was measured using the Kjeldahl method, and crude protein $(\mathrm{CP})$ was calculated as $\mathrm{N} \times 6.25$. Ether extract $(\mathrm{EE})$ was determined through ether extraction. Crude fiber (CF) was measured using acid and alkali treatment. Nitrogen free extract (NFE) was calculated as $100 \%-\mathrm{H}_{2} \mathrm{O} \%-\mathrm{CP} \%-\mathrm{CF} \%-$ Ash\%-EE\%. The neutral detergent fiber (NDF) and acid detergent fiber (ADF) were determined according to the methods of AOAC [13]. Hemicellulose (HC) was calculated according to the formula $\mathrm{HC}=\mathrm{NDF}-\mathrm{ADF}$.

All the chemical analyses were conducted in triplicate, and the results were expressed on a DM basis except for DM content (\% fresh matter) and $\mathrm{NH}_{3}-\mathrm{N}(\% \mathrm{TN})$.

\section{In situ nutrient digestibility}

Six Dorset $\times$ Small Tail Sheep (Local Breed) rams with ruminal cannula and an average of $59.2 \pm 6.3 \mathrm{~kg}$ (mean \pm standard deviation) body weight were used to measure nutrients ruminal digestion. All animals were cared for according to the Chinese standards for the use and care of research animals ([2020] NO.10, GAU). The total mixed ration (TMR) was 
formulated to meet the nutrient requirements of a ram gaining $50 \mathrm{~g} / \mathrm{d}$ according to the mutton sheep breeding standards (NY / T816-2004), Agricultural Industry Standards of the People's Republic of China. The forage to concentrate ratio was approximately 70:30 (1.6 kg/d corn straw silage and concentrate supplement). The ingredient and nutrient compositions of the TMR are given in Table 1 . The TMR was mixed daily (Animal Husbandry Machinery Co., LTD., Hebei, China) and provided twice daily at 9:00 A.M. and 5:00 P.M. with ad libitum access to drinking water.

The DM, NDF, HC, and ADF disappearance were measured according to the standardized procedures of Harazim and Paveleck [14]. Five grams of sample were weighed and sealed in nylon bag $(4 \mathrm{~cm} \times 5 \mathrm{~cm})$ with $38 \mu \mathrm{m}$ pore size (Gansu Alvi Scientific Instrument Co. LTD, Lanzhou, China). Bags were placed into the rumens of the six sheep and incubated for $48 \mathrm{~h}$, totaling six bags for each treatment. Upon removal from the rumen, bags were rinsed immediately under cold tap-water with subsequent washing in a tub with $38^{\circ} \mathrm{C}$ water until the rinse water was clear. The residues were dried, weighed and ground to pass through a $1 \mathrm{~mm}$ screen using a grinding mill (SJP-500A Jinsui Mechanical Equipment Co., China). Then, the samples were thoroughly mixed and analyzed for nutrient composition as previously described.

\section{Nutrient yields}

Yield of DM ( $\mathrm{g} / \mathrm{kg}$ ) was calculated according to DM content,

Table 1. Ingredient composition and nutrient concentrations of the experimental diet

\begin{tabular}{|c|c|}
\hline Items & \\
\hline \multicolumn{2}{|l|}{ Ingredient (\% As is) } \\
\hline Corn straw silage & 72.96 \\
\hline Corn & 14.41 \\
\hline Bran & 4.00 \\
\hline Rapeseed meal & 3.59 \\
\hline Cottonseed meal & 3.86 \\
\hline 1\% Premix ${ }^{1)}$ & 0.29 \\
\hline Calcium bicarbonate & 0.31 \\
\hline Mineral meal & 0.31 \\
\hline Salt & 0.28 \\
\hline Total & 100.00 \\
\hline \multicolumn{2}{|l|}{ Nutrient (\% of DM) } \\
\hline DM (\%) & 36.2 \\
\hline $\mathrm{DE}(\mathrm{MJ} / \mathrm{kg})$ & 14.1 \\
\hline ME (MJ/kg) & 11.5 \\
\hline $\mathrm{CP}(\%)$ & 14.7 \\
\hline $\mathrm{Ca}(\%)$ & 0.76 \\
\hline$P(\%)$ & 0.65 \\
\hline \multicolumn{2}{|c|}{$\begin{array}{l}\text { DM, dry matter; } \mathrm{DE} \text {, digestible energy; } \mathrm{ME} \text {, metabolizable energy; } \mathrm{CP} \text {, } \\
\text { crude protein. } \\
\text { 1) } 1 \% \text { premix contained mineral elements ( } \mathrm{mg} / \mathrm{kg}): \mathrm{Fe}\left(\mathrm{FeSO}_{4} \cdot 7 \mathrm{H}_{2} \mathrm{O}\right), 25 \text {; } \\
\mathrm{Zn}\left(\mathrm{ZnSO}_{4} \cdot 7 \mathrm{H}_{2} \mathrm{O}\right), 40 ; \mathrm{Cu}\left(\mathrm{CuSO}_{4} \cdot 5 \mathrm{H}_{2} \mathrm{O}\right), 8 ; \mathrm{I}(\mathrm{KI}), 0.3 ; \mathrm{Mn}\left(\mathrm{MnSO}_{4} \cdot 5 \mathrm{H}_{2} \mathrm{O}\right) \text {, } \\
40 ; \mathrm{Se}\left(\mathrm{Na}_{2} \mathrm{SeO}_{3}\right), 0.2 ; \mathrm{Co}\left(\mathrm{CoCl}_{3} \cdot 6 \mathrm{H}_{2} \mathrm{O}\right), 0.1 \text {; vitamin }(\mathrm{IU} / \mathrm{kg}) \text { : vitamin A, } \\
\text { 940; vitamin } \mathrm{E}, 20 \text {. }\end{array}$} \\
\hline
\end{tabular}

yield of NDF $(\mathrm{g} / \mathrm{kg})$ was determined by NDF concentration. Yield of digestible DM (dDM, $\mathrm{k} / \mathrm{kg})$ and digestible NDF (dNDF, g/kg) were calculated according to DM and NDF yields and their digestibility, respectively.

\section{Statistical analyses}

All data were subjected to least-squares analysis of variance using the PROC general linear model procedure of SAS (SAS Institute Inc., Cary, NC, USA) [15]. The model included the main effect of three additives (ADD) and two filling methods (FMs) and their interaction. Duncan's multiple range tests were used to detect statistical significance between treatment groups. In all cases, $\mathrm{p} \leq 0.05$ was considered to be statistically significant.

\section{RESULTS}

\section{Effects on silage fermentation characteristics and nutrient composition}

Significant differences were found on corn silage fermentation characteristics between different treatments at two filling times. All items showed good silage fermentation results under MAX treatment at either filling one time or three times $(\mathrm{p}<0.01)$. With respect to filling time, there was higher silage quality under all additives treated with filling one time than those treated with three times $(\mathrm{p}<0.01)$. There were significant differences for all fermentation indexes under interactions of $\mathrm{FM} \times \mathrm{ADD}(\mathrm{p}<0.01)$ except propionic acid. Although the $\mathrm{pH}$ was similar among treatments under different filling methods, it was lower under MAX and MIX than that under CTRL for F1 (3.48 and 3.58 vs 3.80 on average, respectively), but there was the same value of 3.23 under different ADD treated with F3. The content of LA treated with MAX improved by $24.09 \%$ and $0.62 \%$ than CTRL and MIX at F1 while improved by $24.19 \%$ and $4.39 \%$ at F3 respectively. For acetic acid, propionic acid and butyrate acid, all of them treated with MAX and MIX were lower than those treated with CTRL either at F1 or F3. And the value of acetic acid/propionic acid treated with MAX was significantly higher than that of MIX and CTRL at two FMs (Table 2). Except for DM, DMLR, and EE, the other nutrients in corn silage were not affected by either FM or ADD. The highest DM content and lowest DMLR occurred in MAX treatment either at F1 or F3 ( $\mathrm{p}<0.01)$. In fact, the nutrients such as $\mathrm{CP}, \mathrm{NFE}, \mathrm{ADF}$, and $\mathrm{HC}$ showed a higher forage quality under MAX and MIX treatments compared to CTRL, although there were no significant differences among them ( $p>0.05)$ (Table 3). But compared to the initial nutrients before ensiling, the content of DM, CP, NFE, NDF, ADF, and $\mathrm{HC}$ decreased after $60 \mathrm{~d}$ ensiling, except for $\mathrm{CF}, \mathrm{EE}$, and Ash.

Effects on digestibility and yield of digestible nutrients 
Table 2. Effects of filling method and additives on fermentation characteristics (\% of dry matter unless noted otherwise) of whole plant corn silage

\begin{tabular}{|c|c|c|c|c|c|c|c|c|c|c|}
\hline \multirow{2}{*}{ Measurements } & \multicolumn{3}{|c|}{$F_{1}{ }^{1)}$} & \multicolumn{3}{|c|}{$F_{3}{ }^{1)}$} & \multirow{2}{*}{ SE } & \multicolumn{3}{|c|}{ p-value ${ }^{2)}$} \\
\hline & CTRL & MAX & MIX & CTRL & MAX & MIX & & FM & ADD & $\mathrm{FM} \times \mathrm{ADD}$ \\
\hline $\mathrm{pH}$ & $3.80^{a}$ & $3.58^{b}$ & $3.48^{b}$ & $3.23^{c}$ & $3.23^{c}$ & $3.23^{c}$ & 0.057 & $<0.001$ & 0.026 & $<0.001$ \\
\hline Latic acid (\%) & $6.08^{e}$ & $8.01^{a}$ & $7.96^{c}$ & $6.05^{f}$ & $7.98^{\mathrm{b}}$ & $7.63^{d}$ & 0.0058 & $<0.001$ & $<0.001$ & $<0.001$ \\
\hline Acetic acid (\%) & $2.65^{b}$ & $1.37^{f}$ & $1.89^{d}$ & $2.83^{\mathrm{a}}$ & $1.75^{\mathrm{e}}$ & $2.01^{\mathrm{C}}$ & 0.0058 & $<0.001$ & $<0.001$ & $<0.001$ \\
\hline Propionic acid (\%) & $0.08^{b}$ & $0.01^{e}$ & $0.03^{d}$ & $0.10^{\mathrm{a}}$ & $0.04^{d}$ & $0.06^{c}$ & 0.0053 & $<0.001$ & $<0.001$ & $<0.001$ \\
\hline Butyrate acid (\%) & $0.06^{a}$ & $0.01^{c}$ & $0.02^{c}$ & $0.07^{a}$ & $0.04^{b}$ & $0.06^{a}$ & 0.0053 & $<0.001$ & $<0.001$ & $<0.001$ \\
\hline Volatile fatty acids (\%) & $2.79^{b}$ & $1.39^{f}$ & $1.94^{d}$ & $3.00^{\mathrm{a}}$ & $1.83^{e}$ & $2.13^{c}$ & 0.011 & $<0.001$ & $<0.001$ & $<0.001$ \\
\hline Acetic acid/propionic acid & $33.13^{\mathrm{c}}$ & $137.00^{\mathrm{a}}$ & $63.00^{b}$ & $28.30^{c}$ & $43.75^{\mathrm{C}}$ & $33.50^{c}$ & 6.53 & $<0.001$ & $<0.001$ & $<0.001$ \\
\hline
\end{tabular}

SE, standard error.

1) F1, silage filled 1 time; F3, silage filled 3 times; CTRL, no treatment; MAX, treated with Sila-Max (Ralco. Nutrition Inc., Marshall MN, USA); MIX, treated with Sila-Mix (Ralco. Nutrition Inc., USA).

${ }^{2)} \mathrm{FM}$, main effect of filling method; $A D D$, main effect of additive treatment; FM $\times A D D$, interaction of filling method and additive treatment.

${ }^{a-f}$ Means in rows with unlike superscripts differ, $p<0.05$.

\section{of corn silage}

The ADF digestibility (ADFD), NDF digestibility (NDFD), and $\mathrm{CP}$ digestibility (CPD) of silage treated with MAX at two filling times were higher than those treated with CTRL and MIX, but they were not different between treatments except for CPD. For each treatment, filling times affected the results significantly $(\mathrm{p}<0.01)$; ADFD, NDFD, and CPD of each additive filled one time were all higher than those filled three times $(p<0.01)$. The interaction between FM and ADD showed no differences (Table 4). The yield of dDM and dNDF at two FMs showed higher results under MAX treatment. For same ADD, $\mathrm{dDM}$ and $\mathrm{dNDF}$ of silage forage filled one time were higher than those filled three times $(\mathrm{p}<0.01)$ (Table 4).

\section{DISCUSSION}

Fermentation profile, silage quality and yields of digestible nutrients

After $60 \mathrm{~d}$ of ensiling, all corn silage showed excellent fermentation characteristics, which was indicated by dominant LA content as well as negligible propionic and butyric acid. This change can be ascribed to the presence of a sufficient fermentable substrate of the whole corn plant in the milk stage to the ripeness stage as the test material used in the experiment. But further research is still required to clarify why there was higher LA percent compared to CTRL under MAX at F3 than that of F1. Water-soluble carbohydrate (WSC) content along with the activity of epiphytic LAB determines the rate of decline in $\mathrm{pH}$ during the early stages of ensiling, which

Table 3. Nutrient composition (\%) of whole plant corn silage as influenced by filling method and additive after $60 \mathrm{~d}$ of ensiling

\begin{tabular}{|c|c|c|c|c|c|c|c|c|c|c|c|}
\hline \multirow{2}{*}{ Nutrients } & \multirow{2}{*}{$\begin{array}{l}\text { Before } \\
\text { ensiling }\end{array}$} & \multicolumn{3}{|c|}{$\mathbf{F}_{1}{ }^{1)}$} & \multicolumn{3}{|c|}{$\mathbf{F}_{3}{ }^{1)}$} & \multirow{2}{*}{ SE } & \multicolumn{3}{|c|}{ p-value ${ }^{2)}$} \\
\hline & & CTRL & MAX & MIX & CTRL & MAX & MIX & & FM & ADD & $\mathrm{FM} \times \mathrm{ADD}$ \\
\hline $\mathrm{DM}(\%)$ & 25.39 & $20.08^{\mathrm{ab}}$ & $20.93^{a}$ & $20.48^{a}$ & $17.95^{d}$ & $19.30^{\mathrm{bc}}$ & $19.04^{c}$ & 0.26 & $<0.001$ & 0.013 & $<0.001$ \\
\hline DMLR (\%) & - & $21.23^{c}$ & $18.16^{c}$ & $19.87^{\circ}$ & $29.75^{a}$ & $24.44^{b}$ & $25.40^{b}$ & 1.04 & $<0.001$ & 0.015 & $<0.001$ \\
\hline $\mathrm{CP}(\%)$ & 7.30 & 6.31 & 6.79 & 6.49 & 6.26 & 6.69 & 6.38 & 0.18 & 0.558 & 0.221 & 0.982 \\
\hline $\mathrm{EE}(\%)$ & 1.92 & $2.03^{a}$ & $1.75^{\mathrm{bc}}$ & $1.57^{\circ}$ & $2.10^{\mathrm{a}}$ & $1.94^{\mathrm{ab}}$ & $1.94^{\mathrm{ab}}$ & 0.06 & $<0.001$ & 0.002 & $<0.001$ \\
\hline CF (\%) & 22.47 & $26.49^{\mathrm{ab}}$ & $25.98^{b c}$ & $25.62^{c}$ & $27.38^{a}$ & $25.77^{\mathrm{bc}}$ & $26.67^{\mathrm{ab}}$ & 1.05 & $<0.001$ & 0.817 & $<0.001$ \\
\hline Ash (\%) & 5.53 & $5.85^{b}$ & $5.83^{b}$ & $5.77^{b}$ & $6.80^{a}$ & $6.15^{\mathrm{ab}}$ & $6.12^{\mathrm{ab}}$ & 0.23 & $<0.001$ & 0.273 & $<0.001$ \\
\hline NFE (\%) & 57.81 & 48.58 & 49.64 & 49.43 & 47.60 & 49.25 & 48.72 & 0.92 & 0.376 & 0.664 & 0.948 \\
\hline NDF (\%) & 47.20 & $40.33^{\mathrm{ab}}$ & $39.80^{\mathrm{ab}}$ & $37.43^{b}$ & $42.01^{a}$ & $39.43^{\mathrm{ab}}$ & $38.40^{\mathrm{ab}}$ & 1.25 & $<0.001$ & 0.181 & $<0.001$ \\
\hline ADF (\%) & 29.37 & 26.46 & 26.44 & 26.06 & 26.63 & 26.22 & 26.13 & 0.88 & 0.995 & 0.988 & 0.974 \\
\hline $\mathrm{HC}(\%)$ & 17.83 & 13.87 & 13.36 & 11.38 & 15.38 & 13.21 & 12.27 & 1.33 & 0.503 & 0.358 & 0.822 \\
\hline
\end{tabular}

$\mathrm{SE}$, standard error; DM, dry matter; DMLR, dry matter lost rate; CP, crude protein; EE, ether extraction; CF, crude fiber; CA, crude ash; NFE, nitrogen free extract; NDF, neutral detergent fiber; ADF, acid detergent fiber; $H C$, hemicellulose.

1) F1, silage filled 1 time; F3, silage filled 3 times; CTRL, no treatment; MAX, treated with Sila-Max (Ralco. Nutrition Inc., Marshall MN, USA); MIX, treated with Sila-Mix (Ralco. Nutrition Inc., USA).

2) FM, main effect of filling method; $A D D$, main effect of additive treatment; FM $\times A D D$, interaction of filling method and additive treatment.

${ }^{a \cdot f}$ Means in rows with unlike superscripts differ, $p<0.05$. 
Table 4. Digestibility of silage nutrients by sheep and yield of digestible nutrients as affected by filling method and additive

\begin{tabular}{|c|c|c|c|c|c|c|c|c|c|c|c|}
\hline \multirow{2}{*}{ Nutrients } & \multirow{2}{*}{$\begin{array}{l}\text { Before } \\
\text { ensiling }\end{array}$} & \multicolumn{3}{|c|}{$F_{1}{ }^{1)}$} & \multicolumn{3}{|c|}{$F_{3}{ }^{1)}$} & \multirow{2}{*}{ SE } & \multicolumn{3}{|c|}{ p-value ${ }^{2)}$} \\
\hline & & CTRL & MAX & MIX & CTRL & MAX & MIX & & FM & ADD & FM×ADD \\
\hline DMD (\%) & 55.42 & $69.59^{\text {bc }}$ & $71.17^{\mathrm{a}}$ & $67.88^{\mathrm{ab}}$ & $65.50^{d}$ & $65.07^{\mathrm{cd}}$ & $55.54^{d}$ & 3.95 & $<0.001$ & 0.098 & $<0.001$ \\
\hline ADFD (\%) & 30.00 & $44.29^{b}$ & $51.24^{\mathrm{a}}$ & $45.86^{b}$ & $35.56^{c}$ & $36.71^{c}$ & $36.57^{c}$ & 1.72 & $<0.001$ & 0.118 & $<0.001$ \\
\hline NDFD (\%) & 20.93 & $40.77^{\mathrm{ab}}$ & $46.35^{a}$ & $41.12^{\mathrm{ab}}$ & $33.95^{b}$ & $36.18^{b}$ & $36.08^{b}$ & 2.54 & $<0.001$ & 0.505 & $<0.001$ \\
\hline CPD (\%) & 71.00 & $83.72^{b c}$ & $88.49^{a}$ & $84.84^{\mathrm{ab}}$ & $83.73^{c}$ & $79.56^{\mathrm{bc}}$ & $82.52^{c}$ & 1.39 & $<0.001$ & 0.031 & $<0.001$ \\
\hline DM (g/kg) & 253.90 & $200.8^{a}$ & $209.3^{a}$ & $204.8^{a}$ & $179.5^{c}$ & $193.0^{b}$ & $190.4^{b}$ & 0.17 & $<0.001$ & 0.01 & $<0.001$ \\
\hline dDM (g/kg) & 140.71 & $139.74^{b}$ & $148.96^{\mathrm{a}}$ & $139.02^{b}$ & $117.57^{c}$ & $125.59^{c}$ & $105.75^{d}$ & 8.20 & $<0.001$ & 0.01 & $<0.001$ \\
\hline NDF (g/kg) & 472.0 & $403.3^{\mathrm{ab}}$ & $398.0^{\mathrm{ab}}$ & $374.3^{b}$ & $420.1^{\mathrm{a}}$ & $394.3^{\mathrm{ab}}$ & $384.0^{\mathrm{ab}}$ & 7.09 & $<0.001$ & 0.50 & $<0.001$ \\
\hline dNDF (g/kg) & 98.79 & $164.43^{\mathrm{ab}}$ & $184.47^{a}$ & $153.91^{\mathrm{ab}}$ & $142.62^{b}$ & $142.66^{b}$ & $138.55^{b}$ & 7.62 & $<0.001$ & 0.34 & $<0.001$ \\
\hline
\end{tabular}

SE, standard error; DMD, dry matter digestibility; ADFD, acid detergent fiber digestibility; NDFD, neutral detergent fiber digestibility; CPD, crude protein digestibility; dDM, yield of digestible dry matter; dNDF, yield of digestible neutral detergent fiber.

${ }^{1)}$ F1, silage filled 1 time; F3, silage filled 3 times; CTRL, no treatment; MAX, treated with Sila-Max (Ralco. Nutrition Inc., Marshall MN, USA); MIX, treated with Sila-Mix (Ralco. Nutrition Inc., USA).

${ }^{a-d}$ Means in rows with unlike superscripts differ, $p<0.05$.

is important for producing stable silage [16]. Woolford [17] concluded that an initial WSC content between 60 and $80 \mathrm{~g} / \mathrm{kg}$ DM was adequate to produce good-quality grass silage. In this study, WSC in the whole plant corn was $91.2 \mathrm{~g} / \mathrm{kg} \mathrm{DM}$, which is adequate for producing good-quality silage. All silages had $\mathrm{pH}$ values below the threshold of 4 , and very little butyric acid was detected in the samples (Table 2). Control silage had the greatest $(\mathrm{p}<0.05) \mathrm{pH}$ value $(3.80)$, and MAX silage had the lowest value $(\mathrm{p}<0.05 ; 3.48)$, which reflected the differences in their respective LA and acetic acid concentrations, especially for filling one time. Nevertheless, all $\mathrm{pH}$ values were less than four, which indicated that all the forage was adequately fermented.

The literature review published by Muck and Kung [18] established that silage microbial inoculants can alter different aspects of silage fermentation, such as $\mathrm{pH}$, lactic and acetic acid concentrations, DM losses, and DM and fiber digestibility, but the level of effect is variable across studies. In the present study, compared to CTRL, the fermentation aids MIX and MAX with homofermentative LAB enhanced the LA fermentation whether the samples were filled one time or three times. Corn silage treated with MAX especially showed significantly higher LA content, acetic acid/propionic acid values and lower $\mathrm{pH}$ value, acetic acid, propionic acid, butyrate acid, and total VFA compared to MIX and CTRL, which could be attributed to the higher homofermentative LAB in MAX. Wang et al [19] reported that MIX and MAX can reduce ensiling fermentation time and cause the silage to enter LA fermentation in advance by inhibiting negative bacteria activities degrading WSC in the corn plant and reducing the heat produced by aerobic respiration; therefore, the LAB grow rapidly under low-temperature and anaerobic conditions, and sufficient LA production promotes the reduction in $\mathrm{pH}$, which improves the silage quality. That reduced $\mathrm{pH}$ is the reason the acetic acid under MAX and
MIX was lower compared to that in CTRL. Higher LA indicated that the homofermentative bacteria in MAX and MIX did dominate the epiphytic heterofermentative LAB population estimated in forage [20].

Usually, silage fermentation produces volatile compounds, which will often cause the apparent DM\% of silage to decrease compared to fresh material [21]. In present study, the whole plant corn silage treated with MAX showed the highest DM among all silages. Greater DM maintenance due to applying a microbial additive may be attributed to the higher fermentation efficiency of the homofermentative LAB compared to the effects of epiphytic $\mathrm{LAB}$ on forage without an additive. These inoculated bacteria transform sugars into LA without producing secondary metabolites or gases [4]. MAX had some effect on the fiber fraction, which resulted in lower $\mathrm{CF}, \mathrm{NDF}, \mathrm{ADF}$, and $\mathrm{HC}$, although there were no significant differences compared to CTRL and MIX (Table 3), which probably occurred because of acid hydrolysis of HC due to the reduction in $\mathrm{pH}$ from fermentation by LAB [4]. MAX with homofermentative LAB increased residual NFE contents compared to CTRL and MIX, which likely occurred because DM loss by microorganisms was inhibited by MAX, acting as a silage additive to inhibit the use of WSC by undesirable bacteria and reduce silage losses during the early stages of ensiling. These conditions led to the availability of more fermentation substrate for LAB and better fermentation quality [22].

In our study, although no significant differences in DMD, ADFD, and NDFD with the exception of CPD among treatments were observed, MAX slightly increased DMD, ADFD, and NDFD (Table 3) and therefore obtained the higher $\mathrm{CDM}$ and dNDF under two filling times ( $p>0.05$ ) (Table 4). Weinberg et al [23] compared the effects of 10 sources of LAB on in vitro DMD and NDFD of corn silages and found that DMD improved with some inoculants, whereas NDFD did 
not. The authors concluded that this effect might be due to some solubilization of $\mathrm{HC}$ during ensiling, which improved DMD but did not change or even decreased the digestibility of the residual NDF. The present study had lower CPD after treatment with MAX, which likely contributed to the acid produced by LAB fermentation reducing the apparent digestibility of $\mathrm{CP}$ in the rumen and increasing the proportion of bypass protein flowing to the duodenum. This result is consistent with the data of Broderick [24], who reported that the addition of acid to silages prevents $\mathrm{CP}$ hydrolysis and conversion of $\mathrm{CP}$ to ammonia.

\section{Fermentation profile, silage quality and digestible} nutrient yield

Knowledge about the effects of ensiling conditions, e.g., delayed sealing and air infiltration during the ensiling process, is still rare [19]. In farming practice, delayed sealing is often necessary as a result of weather conditions making it difficult to collect forage, because there is insufficient forage to fill the silo at one time, and for other reasons, all of which will lead to air infiltration and oxygen residual during the ensilage process, especially if the silo must be filled several times. Residual oxygen in silage can impair the growth rate of some homofermentative bacteria [25], which results in a decline in the LA concentration [26]. Conflicting results have been reported on the effects of delayed sealing and air infiltration on acetic acid and the production of volatile organic compounds, especially ethanol [27]. In our study, silage filled one time was clearly superior with respect to higher LA synthesis, acetic to propionic acid ratios, and lower $\mathrm{pH}$, acetic acid, propionic acid and butyrate acid compared to silage filled three times (Table 2), which contained residual oxygen. This effect may be attributed to prolonged respiration processes by plant enzymes or several epiphytic aerobic microorganisms competing with LAB for fermentable carbohydrates [28]. In addition, the increase in acetic acid observed in silages filled three times $(\mathrm{p}<0.01)$ is attributable to the presence of residual oxygen, alcohol and aldehyde dehydrogenases produced by Acetobacter and Gluconobacter, which can convert ethanol produced after ensilage for $60 \mathrm{~d}$ to acetic acid [29]. McEniry et al [30] found slightly lower stability and a faster rise in temperature, but these factors were not analyzed in our studies.

Additionally, compared to silage filling times, silage filled one time had higher DM and lower DMLR, EE and Ash ( $\mathrm{p}<$ 0.01). Although other nutrient indexes also have consistent results, they showed no biological significance (Table 3). Therefore, higher nutrient digestibility (DMD, NDFD, ADFD, and $\mathrm{CPD}$ ) (Table 3) and digestible nutrient yield (dDM and dNDF) (Table 4) were attained. This finding cannot be discussed in relation to other published data because, to the best of our knowledge, this study is the first time that this factor has been tested in this manner. Thus, delayed sealing may have directly or indirectly affected the metabolic activity of potential n-propanol producers [27]. Unfortunately, additional studies on the effects of residual oxygen or air infiltration on the fermentation process are not available. Finally, large variations in the fermentation pattern, nutrient value, and nutrient digestibility may be responsible for the observed differences among studies investigating the complexity of the silage fermentation process and the inhabitant microbial ecosystem.

\section{CONCLUSION}

After $60 \mathrm{~d}$ of ensiling, due to sufficient fermentable substrate and epiphytic LAB in whole plant corn, all corn silages showed good fermentation attributes $(\mathrm{pH}<4.0)$. MAX with homofermentative LAB enhanced the LA fermentation, silage quality and nutrient digestibility, compared to CTRL and MIX, and the digestible nutrient yield was also improved, which showed that MAX can be popularized and used in farm corn silage practice in northern China. Silages treated with all additives filled one time, compared to samples filled three times, attained good fermentation qualities; this finding indicates that residual oxygen during ensiling can impair the growth rate of some homofermentative bacteria and lead to a decline in LA concentration and silage quality. Therefore, filling the silo one time is recommended in ensiling process if the conditions are suitable.

\section{CONFLICT OF INTEREST}

We certify that there is no conflict of interest with any financial organization regarding the material discussed in the manuscript. David P. Casper is an employee of Casper's Calf Ranch.

\section{FUNDING}

Modern Herbivore Industry Technology System in Gansu Province (grant number GARS-CS-4); Science and Technology Innovation Fund by Gansu Agricultural University (Young Tutor Support Fund) (grant number GAU-QDFC-2018-04); Special Fund for Agro-scientific Research in the Public Interest (grant numbers 201503134 and 201303059); Earmarked Fund for Modern China Wool and Cashmere Technology Research System (grant number CARS-40-09B).

\section{ACKNOWLEDGMENTS}

The authors would like to thank the Gansu Agricultural University, Lanzhou, China, and the Director of the South Dakota Agricultural Experiment Station for financial support of this research project. The authors also express their 
appreciation to the farm crew and personnel at the Lintao Dairy and Animal Research Farm for the care of the animals. We greatly appreciate Ting Liu, Shuru Cheng, Shengguo Zhao, Jianyong Liang and Xiongxiong Li for their assistance with sample collection and analysis. The authors gratefully acknowledge Ralco, Inc., Marshall, $\mathrm{MN}$, for providing the additives Max and MIX used in this research.

\section{REFERENCES}

1. Zhang FW, Song XF, Zhang XK, Zhang FY, Wei WC, Dai F. Simulation and experiment on mechanical characteristics of kneading and crushing process of corn straw. Transactions of the Chinese Society of Agricultural Engineering; 2019; 35:58-65.

2. Wang DF, Buckmaster DR, Jiang Y, Hua JJ. Experimental study on baling rice straw silage. Int J Agric Biol Eng 2011; 4:20-5.

3. Lan XL, Guo YM, He JL. Research review on the technology of stalk utilization in China. Anhui Agric Sci Bulletin 2013; 19:103-4.

4. Hu YQ, He YY, Gao S, et al. The effect of a diet based on rice straw co-fermented with probiotics and enzymes versus a fresh corn Stover-based diet on the rumen bacterial community and metabolites of beef cattle. Sci Rep 2020;10:10721. https://doi.org/10.1038/s41598-020-67716-w

5. Kung L, Taylor CC, Lynch MP, Neylon JM. The effect of treating alfalfa with Lactobacillus buchneri 40788 on silage fermentation, aerobic stability, and nutritive value for lactating dairy cows. J Dairy Sci 2003;86:336-43. https://doi.org/10. 3168/jds.S0022-0302(03)73611-X

6. Kleinschmit DH, Kung L. The effects of Lactobacillus buchneri 40788 and Pediococcus pentosaceus R1094 on the fermentation of corn silage. J Dairy Sci 2006;89:3999-4004. https:// doi.org/10.3168/jds.S0022-0302(06)72443-2

7. Savage RM, Windle MC, Johannismeier SD, Kung Jr L. The effects of strains of yeasts or Lactobacillus buchneri 40788 on the fermentation, production of volatile organic compounds (VOCs) and aerobic stability of corn silage. J Dairy Sci 2014; 97:537-8.

8. Nishino N, Wang C, Li, Y, Parvin S, Kan K. Occurrence and survival in whole crop corn silage of Acetobacter pasteurianus. In: Proceedings of XVth International Silage Conference. Dairy Forage Research Center; USDA-ARS: Madison, WI, USA; 2009. p. 165-6.

9. Auerbach H, Weiss K, Nadeau E. Benefits of using silage additives. In: Auerbach H, Lückstädt C, Weissbach F, editors. Proceedings of 1st International Silage Summit, Leipzig, Saxony, Germany. Worthington, UK: Anytime Publishing Services; 2010. pp. 75-144.

10. Wang JF, Lei ZM, Cheng SR, et al. Effects of lactic acid bacteria preparation and bran on corn silage quality. Acta
Prataculturae Sinica, 2018;27:162-9.

11. Nishino N, Uchida S. Laboratory evaluation of previously fermented juice as a fermentation stimulant for lucerne silage. J Sci Food Agric 1999;79:1285-8. https://doi.org/10.1002/ (SICI)1097-0010(19990715)79:10<1285::AID-JSFA362> 3.0.CO;2-M

12. Broderick GA, Kang JH. Automated simultaneous determination of ammonia and total amino acids in ruminal fluid and in vitro media. J Dairy Sci 1980;63:64-75. https://doi. org/10.3168/jds.S0022-0302(80)82888-8

13. Latimer GW; AOAC International. Official methods of analysis of AOAC International. 19th ed. Gaithersburg, MD, USA: AOAC International; 2012.

14. Harazim J, Pavelek P. Determination of crude protein and amino acids degradability by method in sacco in the rumen. In: Proceeding of international meeting "Expert Seminar on Determination of Nutrients for Ruminants". Opava, Czech Republic: In Czech; 1999. pp. 41-6.

15. Steel RGD, Torrie JH, Dickey D. Principles and procedures of statistics: a biometrical approach. New York, USA: McgrawHill; 1980.

16. Yuan XJ, Guo G, Wen AY, Desta ST, Wang J. The effect of different additives on the fermentation quality, in vitro digestibility and aerobic stability of a total mixed ration silage. Anim Feed Sci Technol 2015;207:41-50. https://doi.org/ 10.1016/j.anifeedsci.2015.06.001

17. Woolford MK. The silage fermentation. NY, USA: Marcel Dekker Inc.; 1984.

18. Muck RE, Kung Jr L. Effects of silage additives on ensiling. In: Silage: Field to feedbunk. Ithaca, NY, USA: Northeast Regional Agricultural Engineering Service (NRAES); 1997. pp. 187-99.

19. Wang B, Wu JP, Yang L, et al. Effects of Sila-Max and SilaMIX II on fermentation efficient of whole plant corn silage. Proceedings of the Sixteenth National Symposium on Animal Genetics and Breeding; 2011. 579 p.

20. Zhang L,Yu CQ, Shimojo M, Shao T. Effect of different rates of ethanol additive on fermentation quality of napiergrass (Pennisetum purpureum). Asian-Australas J Anim Sci 2011; 24:636-42. https://doi.org/10.5713/ajas.2011.10416

21. Porter MG, Murray RS. The volatility of components of grass silage on oven drying and the inter-relationship between dry-matter content estimated by different analytical methods. Grass Forage Sci 2001;56:405-11. https://doi.org/10.1046/j. 1365-2494.2001.00292.x

22. Queiroz OCM, Arriola KG, Daniel JLP, Adesogan AT. Effects of 8 chemical and bacterial additives on the quality of corn silage. J Dairy Sci 2013;96:5836-43. https://doi.org/10.3168/ jds.2013-6691

23. Weinberg ZG, Shatz O, Chen Y, et al. Effect of lactic acid bacteria inoculants on in vitro digestibility of wheat and corn silages. J Dairy Sci 2007;90:4754-62. https://doi.org/10.3168/ 
jds.2007-0176

24. Broderick GA. Desirable characteristics of forage legumes for improving protein utilization in ruminants. J Anim Sci 1995;73:2760-73.

25. Kung L, Stokes MR, Lin CJ. Silage additives. In: Buxton DR, Muck RE, Harrison, editors. Silage science and technology. Agronomy Monographs Vol 42. Madison, WI, USA: ASA, CSSA, and SSSA; 2003. pp. 305-60.

26. Ruxton IB, Clark BJ, Macdonald P. A review on the effects of oxygen on ensilage. Grass Forage Sci 1975;30:23-30. https:// doi.org/10.1111/j.1365-2494.1975.tb01350.x

27. Mills JA, Kung L Jr. The effect of delayed ensiling and application of a propionic acid-based additive on the fermentation of barley silage. J Dairy Sci 2002;85:1969-75. https://doi.org/ 10.3168/jds.S0022-0302(02)74273-2

28. McDonald P, Henderson AR, Heron SJE. The biochemistry of silage. 2nd ed. Bucksbum, England: Chalcombe Puplications; 1991.

29. Yakushi T, Matsushita K. Alcohol dehydrogenase of acetic acid bacteria: structure, mode of action, and applications in biotechnology. Appl Microbiol Biotechnol 2010;86:1257-65.

30. McEniry J, O’Kiely P, Clipson NJW, Forristal PD, Doyle EM. The relative impacts of wilting, chopping, compaction and air infiltration on the conservation characteristics of ensiled grass. Grass Forage Sci 2007;62:470-84. https://doi.org/10. $1111 / j .1365-2494.2007 .00602 . x$ 